\title{
Grammar Learning Strategies in Omani EFL Classes: Type and Relation to Student Proficiency
}

\author{
Ahmed Al Abri \\ Ministry of Education \\ E-mail: ahmedzaher00@gmail.com \\ Fawzia Al Seyabi (Corresponding author) \\ College of Education, Sultan Qaboos University \\ P.O Box: 32, PC 123 \\ E-mail: fawzia@squ.edu.om \\ Salma Al Humaidi \\ College of Education, Sultan Qaboos University \\ P.O Box: 32, PC 123 \\ E-mail: shumaidi@squ.edu.om \\ Abdul Hamid Hasan \\ College of Education, Sultan Qaboos University \\ P.O Box: 32, PC 123 \\ E-mail:abhshk@squ.edu.om
}

Received: Jan. 23, 2017 Accepted: May 16, 2017 Published: May 16, 2017

doi:10.5296/jse.v7i2.10927 URL: https://doi.org/10.5296/jse.v7i2.10927

\begin{abstract}
The current study investigated the types of learning strategies used by Omani grade ten students when learning grammar. It also explored the differences between students of different proficiency levels in using grammar learning strategies. In order to gather data on
\end{abstract}


students' grammar learning strategies, a frequency-based scale was designed and distributed to 170 students from Al Dhakeleya Governorate in Oman. The questionnaire consisted of thirty-eight items covering three types of grammar learning strategies, which were cognitive, metacognitive and socio-affective strategies. The present study revealed that grade ten Omani students used the three types of learning strategies to different extents. The study showed that Omani tenth graders used meta-cognitive strategies more frequently than cognitive and socio-affective strategies. The study also revealed that proficient students used more metacognitive strategies than less proficient students. The study makes a number of recommendations for future practice.

Keywords: Grammar, Strategies, Cognitive, Meta-cognitive, Socio-affective, EFL; Oman 


\section{Introduction}

The last few decades have witnessed a great shift in education from teacher-centered to learner-centered methodology where students' responsibilities of the process of their learning are maximized. Within this learner-centered instruction, more attention has been given to the strategies learners employ in the learning process. Oxford (1990) defines learning strategies as specific actions and thoughts that are employed by learners in order to make learning easier, faster, more self-directed, and more effective. In terms of second language learning, learning strategies are defined by researchers as certain methods, techniques and actions that are intentionally applied by second language learners when they are attempting to increase their learning of the second language (Rubin,1987; Green \& Oxford ,1995).

Like other aspects of the language, grammar plays a very important role in language learning. Ellis (2006) states that many EFL learners view the process of grammar learning as having intellectual knowledge of the language, which makes students feel secure and confident when using the language. Likewise, some EFL teachers think that learning grammar effectively provides the learners with a generative basis on which they can construct their knowledge and enables them to use the language efficiently. EFL learners empower themselves with certain techniques which they use intentionally when learning grammar. These techniques are called grammar learning strategies by which learners gain grammatical knowledge in order to learn language easily, quickly, and more pleasantly. These strategies also make it more likely that new grammar is applied in new situations (Oxford,1990).

Teaching grammar in Oman started with the "Our World Through English" textbooks (OWTE) in the 1980s. Grammar was taught deductively where teachers were asked to explain the grammatical rules explicitly and give examples. Al-Toubi (1998) found that this explicit teaching of grammar caused many problems for learners especially in terms of using the language communicatively. She found that the OWTE textbooks contained controlled language activities, which led to obvious failure in preparing students to use the language communicatively. This lack of communicative practice affected students' views and perceptions of the importance of learning English in Oman (Al-Toubi, 1998; Al-Mahrooqi, 2012). Newmark (1963) is against learning grammar explicitly and he believes learning grammar this way is neither necessary nor sufficient for learning to use a language. Correspondingly, Apple (1993) believes that uncommunicative grammar learning minimizes learners' exposure to the given knowledge and deprives them from thinking critically. Consequently, the passive role that learners play in explicit language learning can negatively affect their abilities for acquiring and developing essential higher-order thinking skills (Al-Issa, 2010).

The launch of the Basic Education system in 1998 brought about major changes in teaching English in Omani schools. The English Language Curriculum Framework (2010) states that "the new curriculum was designed to help students learn the language communicatively through incorporating a multi-layered, task-based approach that is integrated with functional and grammatical aspects". According to the Curriculum Framework (2010), one of the most important objectives of this curriculum is to help children use English for a purpose as well as 
view English as a means of communicating real information. Therefore, in terms of grammar teaching, it is expected that grammar would be taught inductively and communicatively in order to improve students' overall competence of the language. Teaching grammar communicatively increases the communicative competence of which grammatical competence is a major dimension (Van-Dijk, 1986).

Within this communicative framework, students are expected to play a more active role and use strategies that aid their grammar learning process. Researching these strategies in order to identify them and explore the possibilities of teaching them has become a necessity especially that research in this area is scarce compared with studies looking at strategies used in other language areas such as vocabulary and reading. Anderson (2005) maintains that "what is greatly lacking in the research are studies that specifically target the identification of learning strategies that L2 learners use to learn grammar and to understand the elements of grammar".

To help address this gap, the present study attempts to investigate the type of learning strategies that Omani students in grade 10 use to learn grammar as well as the frequency of use of these grammar learning strategies. It also tries to investigate the relationship between students' proficiency in English language and the use of learning strategies in the Omani context.

The current study attempts to answer the following research questions:

1) What types of strategies do English language learners in Oman use to learn English grammar?

2) Are there significant differences between students of different proficiency levels in the type of grammar learning strategies they use?

\section{Review of the literature}

Oxford, Rang Lee and Park (2007) define grammar learning strategies as deliberate actions and thoughts employed by EFL learners in order to learn and/ or use the language easily, effectively and efficiently. These strategies are usually applied to normalize, control and facilitate the learning process (Griffiths, 2008). However, despite the significance of using grammar learning strategies in language learning, researchers and methodologists have made insufficient attempts to offer a comprehensive classification of these strategies. Pawlak (2009) argues that studies on grammar learning are still at the budding stage. Therefore, a comprehensive theoretical framework of grammar learning strategies hasn't been provided yet and thus more research and studies are needed to establish an inclusive taxonomy that could identify and classify what techniques learners use to learn grammar.

One of the most serious attempts to propose a grammar learning taxonomy was made by Oxford, Rang Lee and Park (2007). The researchers tried to make a distinction between three categories of grammar learning strategies that can be linked with three main grammar teaching instructions. The first strategy is reflective of implicit L2 teaching that includes a focus on form, which pays more attention to form in terms of meaning and message conveyance. The second strategy is based on explicit inductive L2 learning which depends on 
using the input data to discover patterns and rules. The last category of grammar learning strategies is applicable to explicit deductive learning that is connected to the application of grammatical rules presented by the teacher in different types of activities. Although this taxonomy is somewhat useful in identifying some grammar learning strategies, it is criticized for having a more teacher-centered perspective than a learner-centered one since it connects learning strategies to teaching methods (Pawlak, 2009). Pawlak also argues that this taxonomy ignores the existing classifications of learning strategies, puts more focus on cognitive devices and neglects other strategy types. It also relies mainly on understanding and remembering grammatical rules without giving enough emphasis to the importance of practicing the grammatical structures.

O'Malley and Chamot (1990) introduced a different typology of learning strategies based on some interviews they did with language experts and novices. They also depended upon doing theoretical analysis of reading comprehension as well as problem solving. They categorized language learning strategies into cognitive, meta- cognitive and social mediating strategies. Cognitive strategies are those strategies that straightforwardly deal with the received information and manipulate it to enhance learning. They involve conscious actions taken by the language learner to tackle the incoming information such as note taking, using resources and organizing information. In addition, O'Mally and Chamot (1990) define meta-cognitive strategies as those strategies that require language learners to plan and think about learning such as planning one's learning, monitoring one's own speech as well as evaluating the success of a certain strategy. The last kind of learning strategies is social strategies that enable learners to learn language through social interaction with others such as parents, relatives, classmates and teachers.

Basing his study on O'Mally and Chamot's classification, Gimeno (2002) used an experimental research design to investigate the effectiveness of teaching students how to use cognitive and meta- cognitive learning strategies in learning grammar. The study showed that the experimental group that used cognitive and meta-cognitive strategies made a significant improvement in their understanding of the grammatical rules than the control group did. The researcher concluded that teaching students how to use learning strategies helps them develop their language competency and encourages them to be autonomous learners.

In Turkey, Sarıçoban (2005) conducted a study to identify the strategies used by Turkish EFL learners when learning English grammar. The researcher administered a questionnaire to find out what grammar learning strategies were used by 100 students. The researcher categorized the learning strategies in his questionnaire according to the taxonomy provided by O'Malley and Chamot (1990), which includes cognitive, meta-cognitive, and social-affective strategies. The results of the study showed that students subconsciously used the cognitive strategies. It was also found that participants needed to use the socio-affective strategies to learn grammar efficiently.

The relationaship between the type of grammar learning startegies used and students' proficiency was also another area that received a lot of attention. For example, Yalçın (2003) used a questionnaire to find out what grammar learning strategies are used by EFL learners 
and tried to explore whether there is a correlation between the learning strategies and the overall language achievement. The results of the study indicated that there is no correlation between students' achievement and the grammar learning strategies applied to learn grammar.

Similarly, Pawlak (2009) investigated the relationship between the grammar learning strategies used by EFL students and second language attainment. The data was collected through a questionnaire and English end-of-year examination grades. The study revealed that there is a weak relationship between grammar learning strategies employed by learners and their language attainment. However, Pawlak argues that there might be other factors affecting students' achievement that makes the results of his study discouraging such as students' preparation to deal with end-of-year examinations as well as the difficulty of these exams.

Likewise, T1lfarlığlu (2005) tried to explore the relationship between the use of grammar learning strategies of first year Gaziantep University students and their language achievement. The study indicated that $70 \%$ of the students use grammar learning strategies in their learning. It also showed that there is no significant difference between successful and unsuccessful students in using learning strategies when learning grammar. Similarly, Yalcin and Rolyal (2005) didn't find a correlation between using grammar learning strategies and students' achievement.

Unlike the studies presented above, the findings of Gürata's (2008) study on grammar learning strategies indicated that there is a significant difference in the total number of learning strategy use among different proficiency levels. It also revealed that pre-intermediate students tend to use more grammar learning strategies than upper-intermediate students do. The study concluded that using grammar learning strategies positively affects students' grammar achievement.

However, some studies showed that high proficiency learners use more strategies than low proficiency learners (Kayaoglu, 2013; Alhaisoni, 2012; Green \& Oxford, 1995; Ehrman \& Oxford, 1995). Kayaoglu (2013) investigated the relationship between the poor and good learners' beliefs about language learning and their language learning strategy use. The results showed that proficient EFL learners use a greater range of language learning strategies compared to poor learners. This tendency was observed in all major types of strategies, which are memory, compensation, cognitive, metacognitive, social and affective.

In a Saudi EFL context, Alhaisoni (2012) investigated the type and frequency of language learning strategies used by Saudi graduate learners. This study also examined the relationship between language learning strategies (LLS) and proficiency level. The findings revealed that the students used LLS with low to medium frequency. Results also showed that students used cognitive and metacognitive strategies the most, whereas they used memory and affective strategies the least. Moreover, the study revealed that high proficiency students used all types of categories of strategies more often than low proficiency students. Similar results were also found by Ehrman and Oxford (1995) and Green and Oxford (1995) who found that high achieving students used metacognitive strategies more frequently.

The above studies provide contradictory results regarding the frequency of strategy use by 
low and high proficiency learners and the relationship between strategy use and proficiency level and/or achievement. Some of the studies mentioned above, however, proved a positive relationship between highly proficient and/or successful learners and strategy use. As an example these studies specifically revealed that high proficeny or successful learners use high levels of strategies such as metacogntive strategies more frequently. The present study further investigates this issue to provide better evidence.

\section{Methodology}

\subsection{Population and sample}

The population of the current study is grade ten students in Omani governmental schools for the academic year 2015/2016. The study took place in Al- Dhakliah governorate, which has a total of 3173 male students and a total of 3127 female students studying in 140 schools. Cluster sampling was used where six intact classes from three male and three female schools were selected. The total number of participants who comprised the sample of the study was 170 students. The six intact classes contained 77 male students and 93 female students.

\subsection{Instruments}

A five-point frequency scale questionnaire was designed to collect data for the study. The questionnaire contained different grammar learning strategies taken from taxonomies that were developed by Oxford (1990), and O'Malley and Chamot (1990). A thorough look at the literature has shown that these taxonomies are the most comprehensive and the most widely used taxonomies in learning strategies research (Sarıçoban, 2005; Gürata, 2008). Three types of grammar learning strategies were included in the questionnaire: cognitive, meta-cognitive and socio-affective strategies. The questionnaire contained three main parts. The first part is the biographical section in which the participants were asked to write some information about themselves such as their names (optional), gender, number in the class register and school name. The second section included the questionnaire items. There was a total of 38 items that were divided into 23 cognitive strategies items, 7 meta-cognitive items and 8 socio- affective items. Students were requested to indicate their personal use of these strategies using a frequency scale that ranged from "always" to "never". The third section asked students to add other strategies they thought they might use when learning grammar that were not included in the questionnaire items.

The questionnaire was first designed in English but it was then translated into Arabic, students' first language and distributed to students during class time to guarantee a high return rate.

Both validity and reliability of the questionnaire were established. The questionnaire was validated by a panel comprising 13 members from both the Ministry of Education and higher education institutions. In order to check the internal reliability of the questionnaire, Cronbach Alpha coefficient for the frequency scale was calculated giving a result of .85 , which indicates a high level of internal consistency.

SPSS software version 18 was used to analyse the collected data. Descriptive statestics such 
as means and standard deviation was used to check how frequently learning strategies were used by the participants. In addition, MANOVA test was used to investigate whether there are significant differences among students of different proficiency levels in using grammar learning strategies.

\section{Results and discussion}

\subsection{The types of grammar learning strategies used by Omani students}

The descriptive statistics in Table 1 show that Omani grade ten students tend to use meta-cognitive strategies (mean=3.3) more frequently than the other two types of strategies. The table also indicates that the total mean of the cognitive strategies is a little higher than the mean of the socio-affective strategies. Therefore, as far as the mean of each category of strategies is concerned, Omani students' use of grammar learning strategies are (1) meta-cognitive (mean=3.31), (2) cognitive (mean=3.28) and (3) socio-affective strategies $($ mean $=3.28)$ respectively. However, the differences in means between the three categories of learning strategies are not high.

Table 1. Means and standard deviation of the three types of grammar learning strategies

\begin{tabular}{|l|c|c|c|}
\hline & $\mathrm{N}$ & Mean & SD \\
\hline Meta-cognitive & 170 & 3.3126 & .67883 \\
Cognitive & 170 & 3.2839 & .64193 \\
Socio-affective & 170 & 3.2809 & .62342 \\
\hline
\end{tabular}

The one-sample t-test shown in Table 2 indicates that Omani grade ten students use the three grammar learning strategies considerably, which proves the importance of these strategies in learning grammar.

Table 2. One sample t-test on grammar learning strategies

\begin{tabular}{|l|c|c|c|}
\hline Strategy type & $\mathrm{T}$ & Df & Sig. (2-tailed) \\
\hline Cognitive & 5.766 & 169 & .000 \\
Meta-cognitive & 6.004 & 169 & .000 \\
Socio-affective & 5.874 & 169 & .000 \\
\hline
\end{tabular}

In order to have a closer look at the means of the items within each main category of grammar learning strategies, Tables 3, 4 and 5 present the means of the cognitive strategies, meta-cognitive strategies and socio-affective strategies respectively. 
Table 3. Means of cognitive strategies in descending order

\begin{tabular}{|c|c|c|}
\hline Cognitive strategies & Mean & SD \\
\hline $\begin{array}{l}\text { 4. I understand the new grammar rule through linking it to the context/situation } \\
\text { in which it is used. }\end{array}$ & 3.89 & 1.0 \\
\hline $\begin{array}{l}\text { 20. I identify the grammar rules that I face difficulty with and exert an effort to } \\
\text { understand them better. }\end{array}$ & 3.74 & 3.2 \\
\hline $\begin{array}{l}\text { 7. When my teacher corrects my grammatical mistake, I practice repeating the } \\
\text { correct form. }\end{array}$ & 3.72 & 1.2 \\
\hline $\begin{array}{l}\text { 10. I use my own language (e.g. simplification, Arabic) to write the use of the } \\
\text { new grammar rule. }\end{array}$ & 3.72 & 1.1 \\
\hline $\begin{array}{l}\text { 9. I take notes when my teacher explains a new grammar rule. (e.g. I write } \\
\text { down the meaning and the usage of the rule). }\end{array}$ & 3.65 & 1.2 \\
\hline $\begin{array}{l}\text { 15. I remember the grammar rule by thinking of its location in the book (e.g. in } \\
\text { the picture, in the dialogue, in my notebook, or on the board). }\end{array}$ & 3.62 & 1.1 \\
\hline 5. I analyze the parts of the newly learnt grammar rule. & 3.58 & 1.2 \\
\hline 14. I memorize a new grammar rule by repeating it several times to myself. & 3.44 & 1.1 \\
\hline $\begin{array}{l}\text { 11. I emphasize the explanation of the new grammar rule and its important } \\
\text { parts by underlining them or coloring them differently. }\end{array}$ & 3.38 & 1.2 \\
\hline 6. I try to deduce the use of the new grammar rule that I come across. & 3.36 & 1.2 \\
\hline $\begin{array}{l}\text { 19. I remember the grammar rule by thinking of the context/situation where it } \\
\text { is used. }\end{array}$ & 3.36 & 1.2 \\
\hline $\begin{array}{l}\text { 13. I practice writing sentences using the new grammar rule to help me } \\
\text { remember its structure. }\end{array}$ & 3.33 & 1.1 \\
\hline $\begin{array}{l}\text { 23. I replace the grammar rule that I am not sure of with another one that I } \\
\text { already know when writing or speaking. }\end{array}$ & 3.27 & 1.2 \\
\hline 16. I regularly review the grammar rule I learn. & 3.24 & 1.0 \\
\hline $\begin{array}{l}\text { 3. When I learn a new grammar rule I compare it with its correspondent rule in } \\
\text { Arabic. }\end{array}$ & 3.20 & 1.3 \\
\hline $\begin{array}{l}\text { 22. I practice using the new grammar rule by writing e-mails, letters or } \\
\text { compositions. }\end{array}$ & 3.17 & 2.6 \\
\hline 21. I use the new grammar rule in my speaking. & 3.15 & 4.1 \\
\hline $\begin{array}{l}\text { 1. When I learn a new grammar rule, I try to link it to other rules that I already } \\
\text { know. }\end{array}$ & 3.01 & 1.0 \\
\hline 17. I practice doing grammar exercises outside the classroom. & 2.81 & 1.1 \\
\hline 12. I draw charts to help me understand the grammar rule I learn. & 2.81 & 1.2 \\
\hline $\begin{array}{l}\text { 2. I categorize the new grammar rule I learn under a group of similar things } \\
\text { (e.g. verbs, tenses, adjectives etc). }\end{array}$ & 2.79 & 1.1 \\
\hline 18. I consult grammar books for better understanding of the new grammar rule. & 2.65 & 1.3 \\
\hline $\begin{array}{l}\text { 8. I combine the new rule I learn with the previous ones to produce longer and } \\
\text { more complex sentences. }\end{array}$ & 2.53 & 1.2 \\
\hline
\end{tabular}

The means of the items belonging to cognitive strategies presented in Table 3 show that there are not any cognitive strategies classified as being always used by students (means range between 4.5 and 5.0). In fact, the highest seven means of the cognitive strategies (items 4, 20, 
$7,10,9,15$, and 5 respectively) fall in the usually ratings (3.5-4.4) which means that $30 \%$ of the cognitive items are usually used by grade ten students.

Item number 4 in the cognitive section, which is (I understand the new grammar rule through linking it to the context/situation in which it is used) scored the highest mean $(M=3.9)$. This might be due to presenting the new grammar rule in interesting and funny situations either in the textbook or by the teacher, which encourages students to remember these situations easily. Therefore, teachers need to be creative in order to be able to establish enjoyable grammar learning situations through which students can easily comprehend the grammatical rule. On the other hand, item number 8 (I combine the new rule I learn with the previous ones to produce longer and more complex sentences) got the lowest mean $(\mathrm{M}=2.5)$, which comes under the "sometimes" category. This shows that students tend to look at grammar as a set of discrete rules that are presented to them one at a time. Another reason could be the type of tasks presented in the text books which require students to practice the new grammar rule without connecting it to previously learnt rules. The second lowest mean in the cognitive category was scored by item 18 " I consult grammar books for better understanding of the new grammar rule", $(\mathrm{M}=2.7)$. The reason behind that could be the lack of English grammar resources at schools or at students' homes. Another reason might be students' inability or reluctance to use these resources because they depend mostly on the teachers' explanation of the grammatical rules.

Table 4 orders the means of the meta-cognitive strategies in a descending order. Similar to the cognitive strategies, there are no meta-cognitive strategies that are "always" used by students. The table also shows that there were no strategies that were "never" used in this category.

Table 4. Means of meta-cognitive strategies in descending order

\begin{tabular}{|l|c|c|}
\hline Meta-cognitive strategies & Mean & S.D \\
\hline $\begin{array}{l}\text { 29. I correct the grammatical mistakes that my teacher has marked in my written } \\
\text { assignments. }\end{array}$ & 3.64 & 1.2 \\
\hline 28. I try to find out why I make grammar mistakes. & 3.53 & 1.2 \\
\hline 25. I imagine the situation in which I can use the newly learnt grammar rule. & 3.40 & 1.1 \\
\hline 27. I prepare for the grammar rule that will be covered before coming to class. & 3.30 & 1.1 \\
\hline 24. I focus on using grammar rules correctly when I speak or write. & 3.22 & 1.1 \\
\hline 30. I notice my friends' grammatical mistakes and correct them. & 3.09 & 1.2 \\
\hline 26. I notice the new grammar rule when they exist in a listening or a reading text. & 2.98 & 1.1 \\
\hline
\end{tabular}

Item number 29 which is, " I correct the grammatical mistakes that my teacher has marked in my written assignments", had the highest mean $(M=3.6)$ followed by item number 28 which is, " I try to find out why I make grammar mistakes". In fact, these were the only meta-cognitive strategies that belong to the "usually" ratings (3.5-4.4). Students' correction of 
their grammartical errors in writing is not a surprising result since English teachers are expected to use a process writing approach when teaching writing where students produce multiple drafts and edit their language error. The lowest mean $(M=3.0)$ in this category of strategies was scored by item number 3, which is, "I notice the new grammar rules when they exist in a listening or a reading text". One possible reason could be that students are trained to focus more on meaning rather than form when they listen to or read a certain text, which is a main feature of communicative language teaching applied in "English for Me" curriculum.

As for the socio-affective strategies, the means are shown in Table 5. Similar to the two previous strategies, there are no items that can be classified as being "always" used by students.

Table 5. Means of socio-affective strategies in descending order

\begin{tabular}{|l|c|c|}
\hline Socio-affective strategies & Mean & S.D \\
\hline $\begin{array}{l}\text { 32. I ask my friends for help when I do not understand my teacher's } \\
\text { explanation of a grammar rule. }\end{array}$ & 3.84 & 1.1 \\
\hline $\begin{array}{l}\text { 34. I understand grammar better when studying with a friend or a } \\
\text { relative. }\end{array}$ & 3.48 & 1.2 \\
\hline $\begin{array}{l}\text { 35. I practice speaking English even when I am worried about } \\
\text { making grammatical mistakes. }\end{array}$ & 3.40 & 1.2 \\
\hline $\begin{array}{l}\text { 31. I ask my teacher to repeat the explanation of the new grammar } \\
\text { rule when I do not understand it. }\end{array}$ & 3.38 & 1.3 \\
\hline $\begin{array}{l}\text { 37. Playing grammar games helps me comprehend grammar rule } \\
\text { better. }\end{array}$ & 3.24 & 1.3 \\
\hline $\begin{array}{l}\text { 33. I ask competent English speakers to correct my spoken } \\
\text { grammatical mistakes. }\end{array}$ & 3.22 & 1.3 \\
\hline $\begin{array}{l}\text { 38. I prefer working on grammar tasks alone rather than working } \\
\text { with classmates. }\end{array}$ & 2.92 & 1.3 \\
\hline $\begin{array}{l}\text { 36. When my teacher corrects my grammar, I ask him/her questions } \\
\text { about my grammatical mistakes. }\end{array}$ & 2.74 & 1.2 \\
\hline
\end{tabular}

The highest means in this category of strategies were (3.8) and (3.5) which belong to items number 32 and 34 respectively. Both of these items are classified under the "usually" rating and they represent $25 \%$ of the socio-affective strategies. Therefore, it can be said that $25 \%$ of socio-affective strategies are used by students "usually", whereas $75 \%$ of them are used by students "sometimes", (ranging between 3.4 and 2.7). While item number 32 "I ask my friends for help when I do not understand my teacher's explanation of a grammar rule" scored the highest mean, the lowest score (2.7) in this type of strategies was scored by item number 36 " When my teacher corrects my grammar, I ask him/her questions about my grammatical mistakes" which came under the "sometimes" rating. This means that students tend to seek help on grammar from their classmates more often than they do with their teachers. The same finding was revealed in Gurata's (2008) study. Carroll and Swain (1993) believe that this happens due to the big number of students in each classroom, which makes it difficult for teachers to provide students with further explanations and adequate feedback. This can be overcome through activating pair work and group work, which helps save time as well as encouraging students to ask questions about their own grammar mistakes and developing 
their learning strategies at the same time.

In conclusion, based on the general means of the three learning strategy types, Omani grade ten students use meta-cognitive strategies more than cognitive and socio- affective strategies. The means of the three types of grammar learning strategies indicate that Omani students use all of these strategies to different extents. However, no strategy was found to be "always" used by students.

\subsection{Differences in using grammar learning strategies among different proficiency levels}

In addition to investigating the different types of learning strategies that grade ten students use when learning grammar, the study has also looked at whether these strategies were different based on students' proficiency levels in English. In order to identify different proficiency levels, the participants were classified according to their results in English in the first semester of the school year. The test content included language aspects that students studied in previous grades. Students who got As and Bs were considered as proficient learners, those who got Cs were considered as average learners and students who got Ds and Es were regarded as less proficient learners.

MANOVA test was used to investigate differences based on proficiency levels. As can be seen in Table 6, the test showed that overall there were no significant differences in grammar learning strategies among students of different proficiency levels (Wilks' Lambda=.239), except for the area of metacognitive strategies $(\mathrm{p}<.05)$.

Table 6. MANOVA test for proficiency and strategy use

\begin{tabular}{|l|c|c|}
\hline Source & Dependant variable & Sig \\
\hline \multirow{3}{*}{ Proficiency } & Cognitive & .144 \\
& Metacognitive & .035 \\
& Socio-affective & .215 \\
\hline
\end{tabular}

In order to identify the groups between which significant and insignificant differerences could be found, LSD was run.

Table 7. Differences between proficiency levels in using meta-cognitive strategies

\begin{tabular}{|l|c|c|c|}
\hline Dependant variable & (I) Proficiency & (J) Proficiency & Sig \\
\hline Metacognitive & 1 & 2 & .264 \\
\hline & & 3 & .005 \\
\hline & 2 & 1 & .264 \\
\hline & & 3 & .096 \\
\hline
\end{tabular}

Note: $1=$ Proficient; $\quad 2=$ Average; $\quad 3=$ Less proficient

As can be seen in Table 7, differences in the use of metacognitive strategies can be particulary seen between proficient students and less proficient students $(\mathrm{p}<.05)$. Proficient students use meta-cognitive strategies more significantly than their less proficient 
counterparts. This might happen because proficient learners normally have more planning, self management and self monitoring skills that enable them to use more meta-cognitive strategies (O'Malley and Chamot, 1990). However, the tests show that there are no significant differences in using cognitive and socio-affective strategies among students of different proficiency levels.

To conclude, there are no significant differences between students of different proficiency levels and the use of all strategies together. However, significant differences between proficiency levels and each type of strategies are found when testing each strategy independently. The significant differences occur between the proficient students and the less proficient ones only in using meta-cognitive strategies; a result that supports the findings of both Ehrman and Oxford (1995), Green and Oxford (1995), and Rao (2016).

\section{Conclusion}

The present study revealed that Omani grade ten students use cognitive, meta-cognitive and socio-affective strategies when they learn grammar. The findings indicate that meta-cognitive strategies are the most commonly used type of strategies among students. It was also revealed that there are no significant differences between students of different proficiency levels in their overall use of grammar learning strategies. However, it was found that proficient students use meta-cognitive strategies more frequently than less proficient students.

Regardless of their proficiency levels, this study indicated that all students use different learning strategies to certain extents. Green and Oxford (1995) maintain that some successful language learners may be aware of some types of learning strategies and they consciously use them in their learning. Nevertheless, even though less competent learners do use learning strategies, they employ them in random and uncontrolled ways (Chamot et al., 1996). The random strategy use may confuse students and lead them to use strategies that do not work well for them. Therefore, Cohen (1998) and Oxford (2001) argue that it is the teachers' duty to raise their students' awareness of strategy use and encourage them to choose various and suitable strategies that successfully work for them. Cohen (1998) and Oxford (2001) further maintain that training students to use learning strategies positively contributes in developing their language competency and generally improves L2 learning.

According to previous studies conducted in the Omani EFL context, Omani students consider grammar instruction very important in second language learning (Al-Kalbani, 2004). Teachers can take advantage of the positive attitudes of students towards grammar by introducing the different learning strategies explicitly to their students through involving them in mixed ability groups where less proficient students can benefit from the strategies used by their more proficient classmates. Moreover, students can also be encouraged to employ the different types of learning strategies especially the ones that scored the highest means. For example, they can be advised to use cognitive strategies such as practicing learning grammar through connecting grammar rules to the situations and contexts in which they were used. In addition, students with low socio-affective skills can be encouraged to interact with their peers and ask their friends about the grammar rules they face difficulties with. 
The duration of the daily English lesson in Omani public schools ranges between 35-40 minutes only, which minimizes students' opportunities of practicing grammar rules. Hence, helping students to become aware of as well as develop their own repertoire of learning strategies would help them become more autonomous learners, which is a main objective of the Basic Education system. Another reason that calls for developing students' own grammar learning strategies is the intensive grammatical aspects that are introduced in the English for Me curriculum. In order to cope with grammar intensity, students should acquire essential skills such as note taking, asking about the committed mistakes, preparing for grammar lessons and connecting grammatical rules to different situations. Stake holders and curriculum designers need to acknowledge the usefulness of these strategies by including them in the "English for Me" syllabus. The effect of teaching students how to use grammar learning strategies can help produce independent learners who are more responsible of their learning.

\section{References}

Al Haisoni, E. (2012). Language Learning Strategy Use of Saudi EFL Students in an Intensive English Learning Context. Asian Social Science, 8(13), 115-127.

Al-Issa, A. (2010). Factors influencing critical thinking in the ELT context. In R. Al Mahrooqi \& V. Tuzlukova (Eds.), The Omani ELT symphony: Maintaining linguistic and socio-cultural equilibrium (pp. 169-202). Muscat, Sultanate of Oman: Sultan Qaboos University Academic Publication Board.

Al-Kalbani, N. (2004). Omani English teachers' and students' perceptions of the role of grammar instruction in EFL teaching and learning. Unpublished master's dissertation. Sultan Qaboos University, Oman.

Al-Mahrooqi, R. (2012). A student perspective on low English proficiency in Oman. International Education Studies, 5(6), 263-271. https://doi.org/10.5539/ies.v5n6p263

Al-Toubi, S. (1998). A perspective on change in the Omani ELT curriculum: Structural to communicative, Unpublished master dissertation. University of Bristol, England.

Anderson, N. (2005). L2 learning startegies. In E. Hinkel (ed.) Handbook on research in second language teaching and learning (pp.757-771) Mahwah, NJ: Erlbaum.

Apple, M. (1993). Official knowledge. New York, NY: Routledge.

Carroll, S. \& Swain, M. (1993). Explicit and implicit negative feedback: An empirical study of the learning of linguistic generalization. Studies in Second Language Acquisition, 15, 357-386. https://doi.org/10.1017/S0272263100012158

Chamot, A. U. Barnhardt, S., Al-Dinary, P. \& Robbins, J. (1996). Methods for Teaching Learner Strategies in the foreign language classroom. In R. L. Oxford, (ED.), Language learning strategies around the world: Cross-cultural perspective (Tech. Rep. No. 13) (pp. 157-187). Honolulu: University of Hawai'i, Second Language Teaching and Curriculum Center. 
Cohen, A. D. (1998). Strategies in learning and using a second language. London: Longman.

Ehrman, M. E., \& Oxford, R. (1995). Cognition plus: correlate of language learning success. Modern Language Journal, 79(1), 67-89. https://doi.org/10.1111/j.1540-4781.1995.tb05417.x

Ellis, R. (2006). Current issues in the teaching of grammar: An SLA perspective. TESOL.

Gimeno, A. (2002). Call Software Design and Implementation: the template approach. Valencia: Servicio de Publicaciones de la Universidad Politécnica de Valencia.

Green, J. M. and Oxford, R. L. (1995). A closer look at learning strategies, L2 proficiency and gender. TESOL Quarterly, 29. 261-297. https://doi.org/10.2307/3587625

Griffiths, C. (2008). Strategies and good language learners. In C. Griffiths (ed.). Lessons from good language learners. Cambridge: Cambridge UP. https://doi.org/10.1017/cbo9780511497667.009

Gürata, A. (2008). The grammar learning strategies employed by Turkish University preparatory school EFL students. MA thesis. The Graduate School of Education of Bilkent University.

Kayaoglu, M. N., (2013). Poor and Good Learners' Language Beliefs and their Influence on their Language Learning Strategy Use. Novitas-Royal (Research on Youth and Language), 7(1), 36-54.

Ministry of Education. (2010). English Language Curriculum Framework. Oman.

Newmark, L. (1963). Grammatical theory and the teaching of English as a foreign language. In M. Lester (ed.) Readings in Applied Transformational Grammar. New York: Holt, Rinehart and Winston.

O' Malley, J. \& Chamot, A. (1990). Learning strategies in second language acquisition. Cambridge: Cambridge University Press. https://doi.org/10.1017/CBO9781139524490

Oxford, R, L. (1990). Language Learning Strategies: What Every Teacher Should Know. New York: Newbury House Publishers.

Oxford, R. L. (2001). Language learning styles and strategies. In M. Celce-Murcia (Ed.), Teaching English as a second or foreign language (3rd ed., pp. 359-366). Boston: Heinle \& Heinle.

Pawlak, M. (2009). Grammar learning strategies and language attainment: Seeking a relationship. Research in Language, 7(1), 43-60.University of Gaziantep. Unpublished Master's thesis, The University of Gaziantep, Gaziantep. https://doi.org/10.2478/v10015-009-0004-7

Rao, Z. (2016). Language Learning Strategies and English Proficiency: Interpretations from Information-Processing Theory. Language Learning Journal, 44(1), 90-106. https://doi.org/10.1080/09571736.2012.733886

Rubin, J. (1987). Learning strategies: Theoretical assumptions, research history and typology. 
In A. Wenden \& J. Rubin (eds.), Learners' strategies in language learning. NY. Prentice Hall.

Sarıçoban, A. (2005). Learner preferences in the use of strategies in learning grammar. Atatürk Üniversitesi Sosyal Bilimler Enstitüsü Dergisi, 5(1), 319-330.

Tilfarloğlu, F. Y. (2005). An analysis of the relationship between the use of grammar learning strategies and student achievement at English preparatory classes. The journal of language and linguistic studies, 1(2), 155-169.

Van-Dijk, T. (1998). Ideology. London, England: Sage.

Wenden, A. \& Rubin, J. (1987). Learner Strategies in Language Learning. Hertfordshire: Prentice Hall. https://doi.org/10.1111/j.1467-1770.1987.tb00585.x

Yalçın, E. (2003). An analysis of the relationship between the use grammar learning strategies and student achievement at English preparatory classes. Journal of Language and Linguistic Studies, 1, 155-169.

Yalcin, F. and Rolyal, E (2005). An Analysis of the Relationship Between the Use of Grammar Learning Strategies and Student Achievement at English Preparatory Classes. Journal of Language and Linguistic Studies, 1(2). 